Journal of MMIJ Vol.131 p.597- 601 (2015)

C2015 The Mining and Materials Processing Institute of Japan

\section{総 説 \\ Review}

\section{南太平洋諸国の排他的経済水域における 海底鉱物資源ポテンシャル *}

\title{
Deep-Sea Mineral Potential in the South Pacific Region
}

\author{
by Nobuyuki OKAMOTO ${ }^{\mathrm{a}}$
}

a. Japan Oil, Gas and Metals National Corporation (JOGMEC)

(Corresponding author, E-mail: okamoto-nobuyuki@jogmec.go.jp, FAX: 03-6758-8058)

The Government of Japan and South Pacific Applied Geoscience Commission (SOPAC) have been conducting joint surveys of deep-sea mineral resources in the Exclusive Economy Zones (EEZs) of SOPAC member countries, since 1985. The various research and government institutions that have been closely involved in this long-standing program include: the Japan International Co-operation Agency (JICA) and Japan Oil, Gas and Metals National Corporation (JOGMEC) which is the former Metal Mining Agency of Japan (MMAJ) and relevant ministries of the participating Pacific Island government.

The survey program is on-going using research vessel Hakurei-Maru No.2 which belongs to JOGMEC.

This twenty year long, joint project initiative has been extremely successful in confirming the resource potential of the Pacific region through discovering valuable deep-sea mineral resources such as polymetallic nodules in the Cook Islands waters, cobalt-rich ferromanganese crusts in the Marshall Islands, Kiribati and Federated States of Micronesia, and polymetallic sulphides in the Fiji waters.

KEY WORDS: SOPAC, South Pacific, Polymetallic Nodules, Cobalt-Rich Ferromanganese Crusts, Polymetallic Sulphides, Deep-Sea Mineral Resources

1. はじめに

南太平洋諸国は, 国土面積は 55 万 $\mathrm{km}^{2}$ と非常に小さいもの の, 大小 7,500の島々によって, その排他的経済水域 (Exclusive Economic Zone: EEZ) は約 3,000 $\mathrm{km}^{2}$ と広大である。ただし, 国土 面積の大半を占めるのはパプア・ニュー・ギニアであり, これ を除くと, 国土面積は 9 万 $\mathrm{km}^{2}$ と非常に小さくなってしまうが, その EEZ はほとんど変わらず $2,700 \mathrm{~km}$ にものぼり, 実に国土面 積の 300 倍 (日本は 12 倍) を誇る (Fig. 1) ${ }^{1)}$ 。

EEZ 内にある海底鉱物資源は, 沿岸国が自国の法律 (日本では 鉱業法) によって, 探査・開発が可能である。このため, 我が国 の EEZ の 6 倍を有する南太平洋諸国にとっては, 水産資源はも とより, 海底鉱物資源の開発は, 地域の持続的な発展のために非 常に重要なことと言える。

\section{SOPAC 調査の概要}

金属鉱業事業団 (当時。現独立行政法人石油天然ガス・金属 鉱物資源機構) は, 南太平洋応用地球科学委員会 (SOPAC: South Pacific Applied Geoscience Commission。現太平洋共同体応用地球

*2014 年 2 月 20 日受付 2014 年 6 月 11 日受理

1. 正会員独立行政法人石油天然ガス・金属釷物資源機構

[ 著者連絡先 ] FAX: 03-6758-8058 E-mail: okamoto-nobuyuki@jogmec.go.jp

キーワード : SOPAC, 南太平洋, マンガン団塊, 海底熱水鉱床, 鉄・マン ガンクラスト, 海底鉱物資源
科学技術部：SPC Applied Geoscience and Technology Division) と呼 ばれる地域間機関からの要請に基づき, 昭和 60 年度 (1985 年度) から, 当事業団所有の深海底鉱物資源探査専用船「第 2 白嶺丸」 を用いて, 南太平洋諸国の EEZにおいて, マンガン団塊, 海底 熱水鉱床及び鉄・マンガンクラストを対象とした海洋資源調査を 国際協力事業団 ( 当時。現独立行政法人国際協力機構 (JICA) ) と 共同で実施してきた ${ }^{2,3,4)}$ 。

本調查は第 I 期と第 II 期に分けられ，そのうち第 1 期は，3つ のフェーズ (5 年間/フェース) からなり, 主に鉱物資源の賦存ポ テンシャルの把握を目的に音響調査やサンプリング調査を実施し た。

平成 12 年度 $(2000$ 年度) からは第 2 期に移行し, 第 I 期調査 で抽出された有望海域について, 深海用ボーリングマシンなどを 用いて, より詳細な調查を実施して概略資源量を把握するとと もに, 併せて将来の開発に必要な水質データや海底の微生物な どの生息状況などの環境ベースラインデータの取得にも努めた (Table 1)。

\section{3. 調査の実績}

21 年間の調査において, 航海日数は延べ 1,000 日を超え, 音 響 ( 音波) 調査のための航走距離は地球 4 周に相当する約 16 万 $\mathrm{km}$, 深海テレビカメラによる海底観察の総延長 $1,350 \mathrm{~km}$, サン プリング約 2,000 点以上と, 膨大な調査データを取得した。これ らの調查結果については, 毎年, クルーズレポートにとりまとめ, 


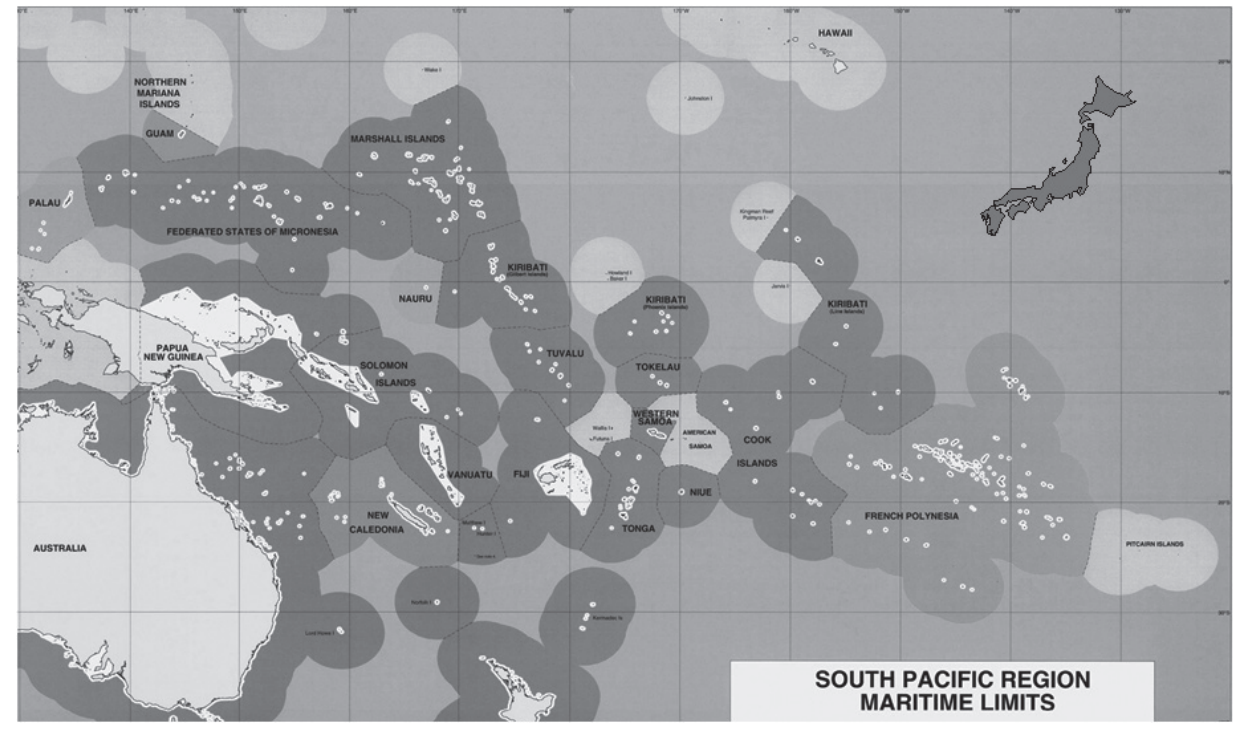

Fig.1 EEZs of SOPAC member countries with land space of Japanese Islands.

Table 1 Areas and mineral resources surveyed within the selected SOPAC member countries.

\begin{tabular}{|c|c|c|c|c|c|}
\hline Stage & Phase & Year & SOPAC Country & Area Surveyed & Mineral Resources \\
\hline \multirow{18}{*}{ I } & \multirow{5}{*}{1} & 1985 & Cook Islands & North Penrhyn Basin & Manganese Nodules \\
\hline & & 1986 & Cook Islands & South Penrhyn Basin & Manganese Nodules \\
\hline & & 1987 & Kiribati & Phoenix Islands Group & Nodules and Crusts \\
\hline & & 1988 & Tuvalu & Ellice Islands and Ellice Basin & Nodules and Crusts \\
\hline & & 1989 & Kirbati & Southern Line Islands & Nodules and Crusts \\
\hline & \multirow{6}{*}{2} & \multirow[t]{2}{*}{1990} & \begin{tabular}{|l|l}
90 Cook Isla \\
\end{tabular} & Southern Cook Islands & Manganese Nodules \\
\hline & & & Samoa & Samoan Islands & Nodules and Crusts \\
\hline & & 1991 & Kirbati & Gilbert Islands Group & Nodules and Crusts \\
\hline & & 1992 & Papua New Guinea & Manus Basin & Hydrothermal Deposits \\
\hline & & 1993 & Solomon Islands & Woodlark Basin & Hydrothermal Deposits \\
\hline & & 1994 & Vanuatu & Coriolis Trough & Hydrothermal Deposits \\
\hline & \multirow{7}{*}{3} & \multirow[t]{2}{*}{1995} & \multirow[t]{2}{*}{ Tonga } & Tonga Ridges & \multirow[t]{2}{*}{ Hydrothermal Deposits } \\
\hline & & & & East Law Basin & \\
\hline & & 1996 & Marshall Islands & Northern part & Cobalt-rich Crusts \\
\hline & & 1997 & FSM & Whole area & Cobalt-rich Crusts \\
\hline & & 1998 & Marshall Islands & Southern part & Cobalt-rich Crusts \\
\hline & & & FSM & Whole area & \\
\hline & & 1999 & Fiji & North Fiji Basin & Hydrothermal Deposits \\
\hline \multirow{7}{*}{ II } & \multirow{3}{*}{1} & 2000 & Cook Islands & South Penrhyn Basin & Manganese Nodules \\
\hline & & 2001 & Fiji & North Fiji Basin & Hydrothermal Deposits \\
\hline & & 2002 & Marshall Islands & Northern and southern part & Cobalt-rich Crusts \\
\hline & \multirow{4}{*}{2} & \multirow{4}{*}{$\begin{array}{l}200 \\
200\end{array}$} & Kiribati & Gilbert Islands Group & Cobalt-rich Crusts \\
\hline & & & Niue & Whole area & Manganese Nodules \\
\hline & & & Fiji & North Fiji Basin & Hydrothermal Deposits \\
\hline & & & & Whole area & Cobalt-rich Crusts \\
\hline
\end{tabular}

SOPAC 事務局や調查対象国 (沿岸国) 一提示した。

\section{4. 調査の方法}

深海底鉱物資源の探査では, (1)まず音響調査等によって海底地 形や海底の様子を大まかに把握し, (2)その後, 深海テレビカメラ によって, 海底の様子をビジュアルに観測し, 産状等の分布状況 を把握し, (3)最後に, 実際に試料を採取して分布密度や鉱床の厚 さ, 品位を測定した。

本調査は, 当機構所有の深海底鉱物資源探査専用船「第 2 白嶺 丸」を用いて実施した。

第 2 白嶺丸は，深海底鉱物資源探査を実施するために求められ る地形図作成, 海底の映像撮影, サンプリングを行うための全て の機器が備わっている (Fig. 2)。特に, 同船は, 日本の地質調査 船の中でも, 特にサンプリング性能が高く, 通常の海底の岩石や

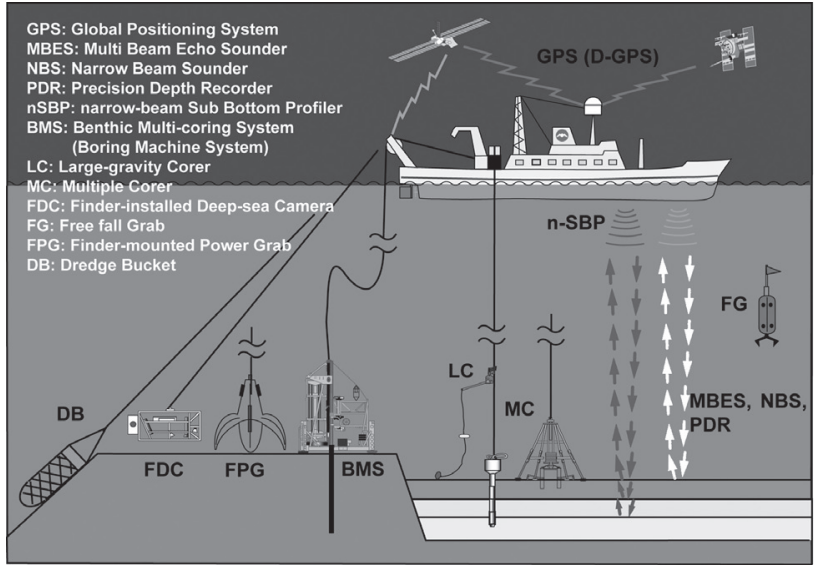

Fig.2 Survey and sampling platform tools of the Hakurei-maru No.2. 


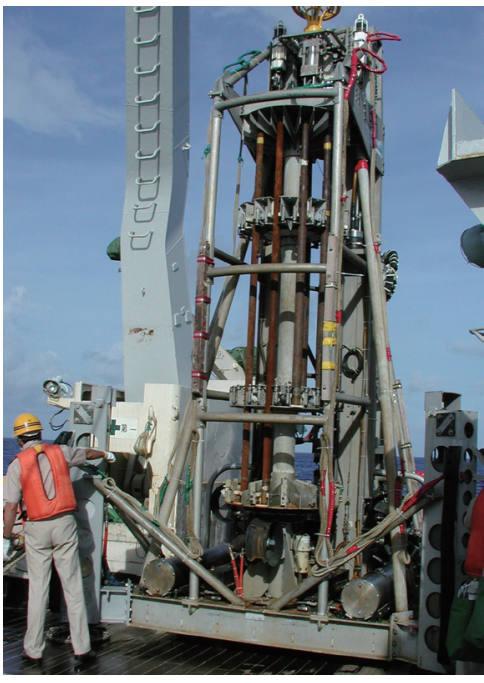

Fig.3 Benthic Multi-coring System.
鉱石を引っ掻いたり, 掴んだりして採取するドレッジやグラブ等 のサンプリング機器の他, 海底下鉛直方向に最大 $20 \mathrm{~m}$ のコア試 料を採取できる深海用ボーリングマシンシステム (BMS) (Fig. 3) が備わっており, 鉛直方向に分布寸るコバルトリッチクラストや 海底熱水鉱床の調査に用いた。

\section{21 年間のプロジェクト成果}

\section{$5 \cdot 1$ マンガン団塊}

マンガン団塊を対象とした海洋資源調査では, クック諸島, キ リバス, ツバル及びサモアの 4 力国の EEZ において, フリーフォー ルグラブ (FG) やスペードコアラ (SC) を用いてサンプリング調査 を実施した。その結果, Fig. 4 に示寸ように, 主にクック諸島海 域において $25 \mathrm{~kg} / \mathrm{m}^{2}$ 以上という非常に高い密度でマンガン団塊が 分布する海域を確認した。また，この海域でのマンガン団塊は， 通常のものに比べてコバルト品位が 2 倍程度高いことも判明した。

この結果を踏まえ, 特にクック中部部の高密度域において, ポ リゴン法を用いて，概略の資源量を計算した ${ }^{5)}$ 。Fig. 5 はクッ

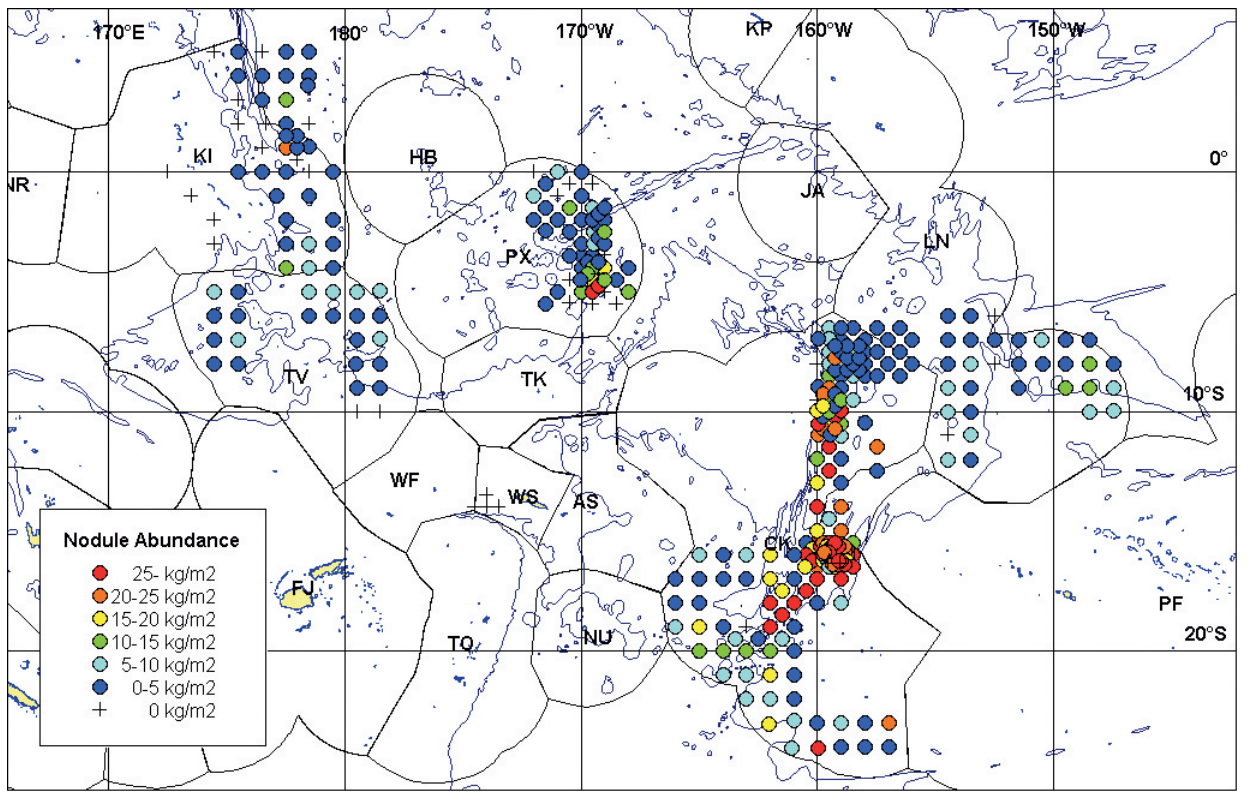

Fig.4 Manganese nodule abundance in the four SOPAC member countries.

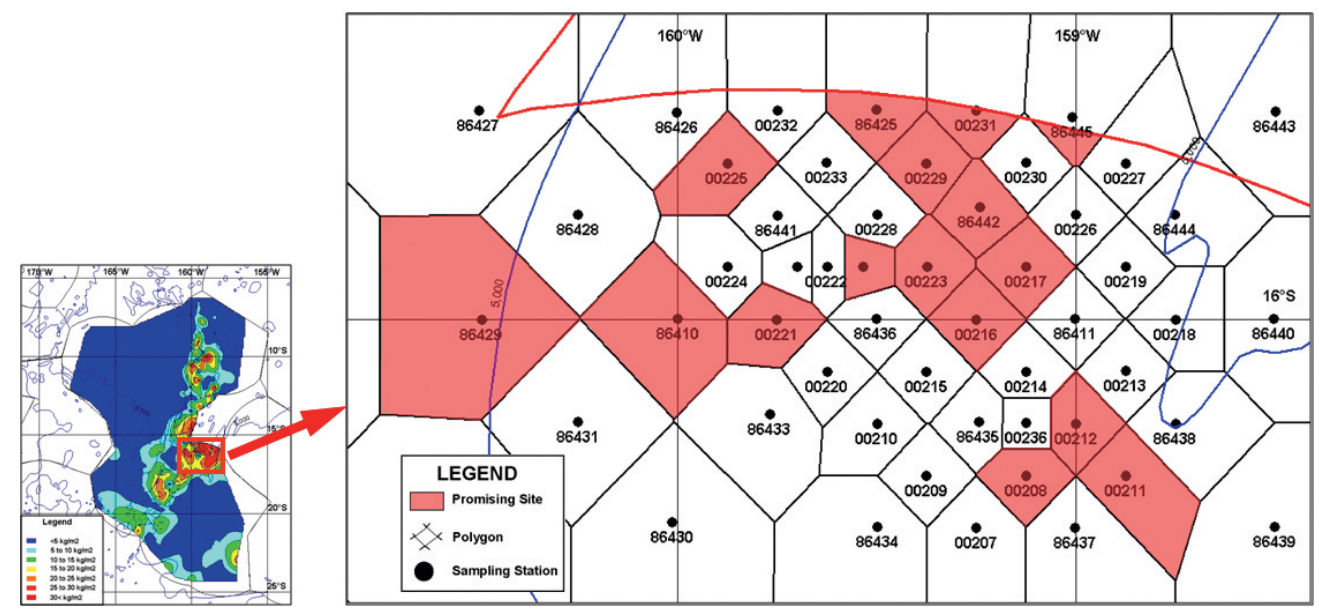

Fig.5 Resource estimates of manganese nodules within the central area of the EEZ of the Cook Islands, using the method of polygons developed by Kohpina and Usui in 1996. 
Table 2 Nodule and cobalt resources in Area 1 located within the EEZ of the Cook Islands.

\begin{tabular}{c|c|c|c|c|c|c}
\hline $\begin{array}{c}\text { Station } \\
\text { No. }\end{array}$ & $\begin{array}{c}\text { Abundance } \\
\left(\mathrm{kg} / \mathrm{m}^{2}\right)\end{array}$ & $\begin{array}{c}\text { Water Content } \\
(\%)\end{array}$ & $\begin{array}{c}\text { Co Grade } \\
(\%)\end{array}$ & $\begin{array}{c}\text { Area } \\
\left(\mathrm{km}^{2}\right)\end{array}$ & $\begin{array}{c}\text { Nodule Resources } \\
\text { (thousand metric ton) }\end{array}$ & $\begin{array}{c}\text { Cobalt Resources } \\
\text { (metric ton) }\end{array}$ \\
\hline 86410 & 33.09 & 31.10 & 0.49 & 1,031 & 23,506 & 115,178 \\
\hline 86425 & 34.57 & 28.6 & 0.48 & 304 & 7,504 & 36,017 \\
\hline 86429 & 31.00 & 31.5 & 0.56 & 2,177 & 46,229 & 258,880 \\
\hline 86442 & 31.54 & 30.5 & 0.55 & 369 & 8,089 & 44,487 \\
\hline 86445 & 32.93 & 26.4 & 0.51 & 99 & 2,399 & 12,237 \\
\hline 00208 & 31.18 & 22.2 & 0.5 & 325 & 7,884 & 39,419 \\
\hline 00211 & 32.39 & 27.93 & 0.54 & 651 & 15,197 & 82,062 \\
\hline 00212 & 31.14 & 23.73 & 0.55 & 325 & 7,719 & 42,454 \\
\hline 00216 & 34.81 & 29.96 & 0.53 & 373 & 9,094 & 48,199 \\
\hline 00217 & 32.16 & 25.99 & 0.46 & 378 & 8,997 & 41,386 \\
\hline 00218 & 36.66 & 23.37 & 0.46 & 403 & 11,321 & 52,078 \\
\hline 00219 & 33.08 & 30.33 & 0.58 & 368 & 8,481 & 49,191 \\
\hline 00220 & 30.44 & 22.94 & 0.46 & 522 & 12,245 & 56,325 \\
\hline 00221 & 32.96 & 27.52 & 0.52 & 369 & 8,815 & 45,839 \\
\hline 00222 & 32.93 & 24.91 & 0.51 & 205 & 5,069 & 25,852 \\
\hline 00223 & 30.63 & 33.63 & 0.44 & 185 & 3,761 & 16,548 \\
\hline Total & & & & 8,084 & 186,309 & 966,153 \\
\hline
\end{tabular}

ク諸島中央部のポリゴンブロック図で，特に $30 \mathrm{~kg} / \mathrm{m}^{2}$ 以上の高 密度部分のみを抽出して，資源量を算定すると，その分布域は $8,000 \mathrm{~km}^{2}$ 以上にもなり，概略資源量として約 2 億トンのマンガ ン団塊が分布し，その中に含まれるコバルトは金属量ベースで 97 万トンが存在することになる (Table 2)。この量は, 日本の消 費量に換算すると約 70 年分に相当する ${ }^{6)}$ 。

\section{$5 \cdot 2$ 鉄・マンガンクラスト}

キリバス, ツバル, サモア, マーシャル諸島及びミクロネシア 連邦 5 力国の EEZ で調査を実施し, 同海域での鉄・マンガンク ラストの賦存状況を把握するとともに, 特にマーシャル諸島, キ リバス (ライン諸島) 及びミクロネシア連邦海域において, クラ ストの発達が顕著な海域を抽出した (Fig. 6)。

マーシャル海域の東部の 3 海山について, 斜面中部以上（平頂 部，斜面上部，斜面中部と区分）の範囲において，ドレッジや深 海用ボーリングマシンによるクラスト層厚・品位データ, 地形区 分ごとの平面積, 比重 (2.0) から, クラスト資源量約 3 億 $\mathrm{t}$, Co 金属量 147 万 $\mathrm{t}, \mathrm{Pt}$ 金属量 $155 \mathrm{t}$ となった ${ }^{7,8)}$ 。なお, これらの算 定值には，採鉱実収率などが加味されていないので，過見積であ るとの指摘もあるため, 今後詳細な検討を行う必要がある9)。

\section{$5 \cdot 3$ 海底熱水鉱床}

パプア・ニュー・ギニア（PNG），ソロモン諸島，バヌアツ， トンガ及びフィジーの 5 カ国の EEZ の拡大軸付近を中心に, 海 底地形調查による拡大軸の抽出や海底観察による熱水活動の把握 に努め, 油圧式パワーグラブ (FPG) 等を用いて, 海底熱水鉱床試 料の採取を行った。

その結果, ソロモン, バヌアツ及びフィジー海域で海底熱水 鉱床の徵候の存在を確認するとともに, 特にフィジー海域では, 海底観察により, 詳細な熱水活動範囲を特定し, 深海用ボーリ ングマシン（BMS）を用いて, 熱水鉱床の厚さ方向の確認に努め た。鉱床の厚さは BMS の結果から最大 $7 \mathrm{~m}$ を確認するとともに (Fig. 7), モデルマウンドの概略資源量を約 7 万トン $(\mathrm{Cu} 6.93 \%$, $\mathrm{Zn} 0.61 \%$, Au0 $0.85 \mathrm{~g} / \mathrm{t}$ 及び $\mathrm{Ag} 24.39 \mathrm{~g} / \mathrm{t}$ ) 算定した。

\section{$5 \cdot 4$ その他の成果}

平成 12 年度 (2000 年度) からの第 2 期においては, 賦存状況 調査だけでなく, 将来の開発に向けて環境ベースラインデータの 取得に努めた。主に, 海底の堆積物中に生息する微生物等を把握 するため, マルチプルコアラ (MC) と呼ばれる堆積物を乱さない ように採取する特殊なサンプリング機器を用いて調查を実施し
た。この結果，クック，フィジー，マーシャル諸島，キリバス， ニウエ及びミクロネシア連邦海域における予察的な環境ベースラ インデータを取得した。これらのデータは, 将来の開発に資する 基礎データとしての活用が期待される。

また, 本調査を通じて, 南太平洋諸国の技術者に海洋調査の方 法・ノウハウ等の海洋調査技術の移転を図ることも重要である。 このため, 毎年, 最低 1 名, 延べ 20 名以上に及ぶ調査対象国の 技術者が洋上研修員として調查航海に参加し, 調査技術を習熟 した。

\section{6. ま と め}

21 年間の調查によって, 南太平洋諸国の EEZ 内の深海底鉱物 資源の賦存状況を把握することができ, 特にクック海域ではマン ガン団塊, マーシャル諸島ではコバルトリッチクラスト, フィジー 海域では海底熱水鉱床を対象とした詳細な調查を実施し, 概略資 源量まで試算することができた。

南太平洋海域での海洋調査は, これまで日本を始め, ドイッ, フランス, 豪州, 米国, 韓国等により, 主に海洋科学調査を中心 に行われてきている。ただし, 本調查プログラムのように, 系統 かつ長期にわたって継続して海底鉱物資源調查を行ってきた国・ 機関はなく, これまでに蓄積されたデータは世界的にも有意義な ものと言える。

近年, 韓国は, トンガやフィジーの EEZで探查権を取得し, 海底熱水鉱床の探查に着手している。また, 民間企業の Nautilus Minerals 社は, PNG 海域での熱水鉱床開発を目指し, 探査や採 鉱システムの開発を継続している。さらに, クック諸島では, 我 が国が取得したデータを用いて国際入札の動きもある。また, 欧 州諸国も海底熱水鉱床調查を行っているとの情報もある。

このように, 南太平洋海域の海底鉱資源開発を巡る動きは依然 として活発であり, 今後もこうした動向に注視していく必要がある。

謝辞本稿をまとめるにあたり, 多大なる便宜を図って頂 いた Applied Geoscience and Technology Division of Secretariat of the Pacific Community (SOPAC Division of SPC), 太平洋諸国の関係皆 様に感謝致します。

また, 本調査の実施にあたり, ご配慮頂いた深海資源開発 ( 株) 及び海洋技術開発 (株) 各位の皆様に感謝します。 


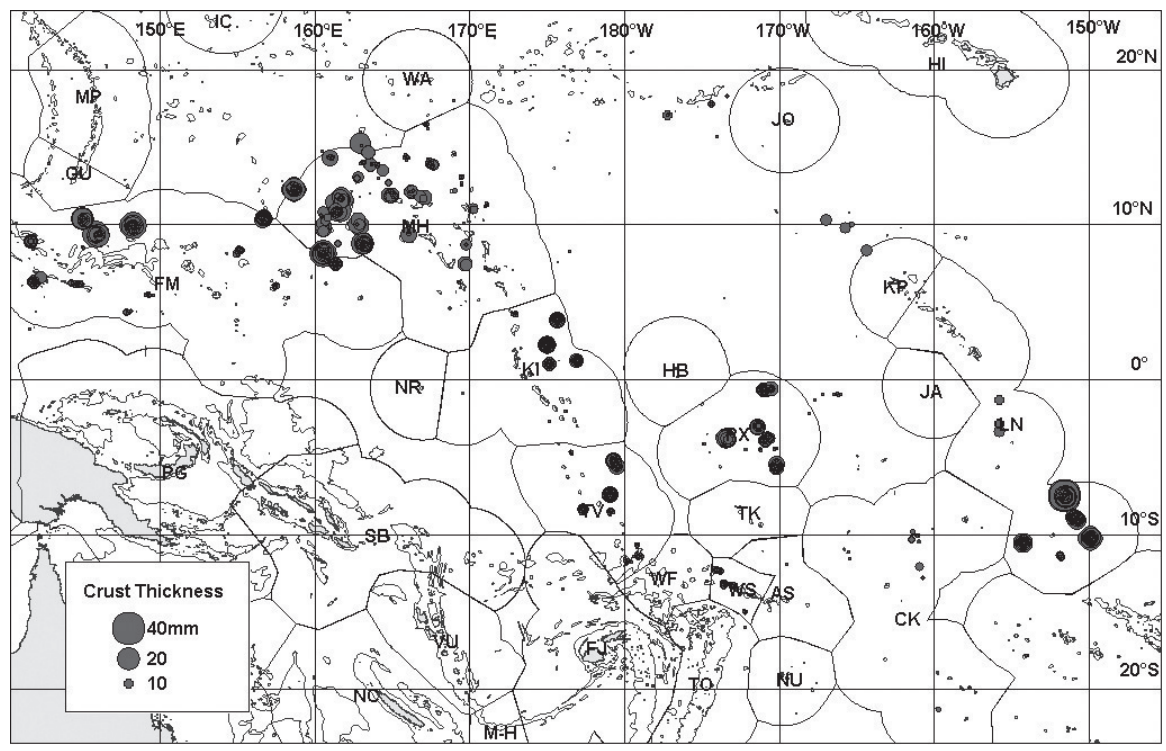

Fig.6 Cobalt-rich ferromanganese crust thickness in SOPAC region studied by the Program.

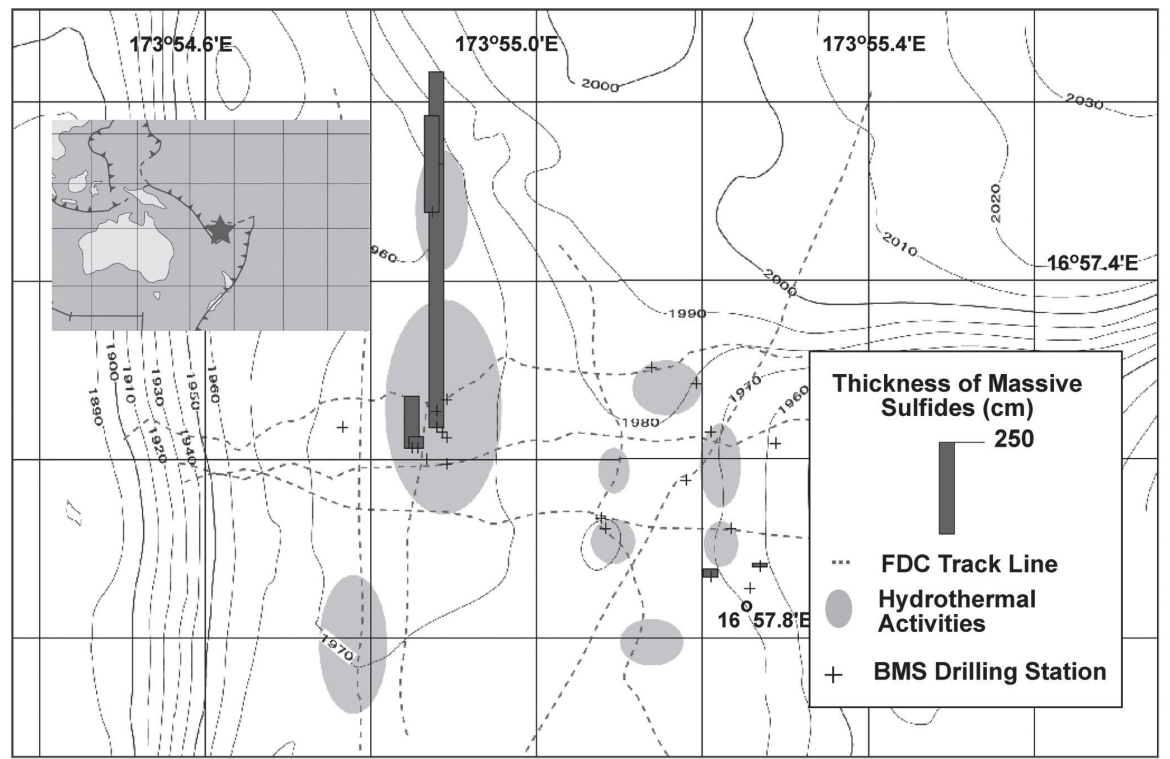

Fig.7 Distribution of the vertical dimension of polymetallic sulphides around the triple junction in the north Fiji basin

\section{References}

1) SOPAC/FFA: South Pacific Region Maritime Limits Map (1995).

2) JICA/MMAJ: Report on the Cooperative Study Project on the Deepsea Mineral Resources in Selected Offshore Areas of the SOPAC Region, Sea area of the Republic of Fiji Islands, Vol.5, (Tokyo,2000).

3) JICA/MMAJ: Report on the Joint Basic Study for the Development of Resources, Ocean Resources Investigation in the Sea Area of SOPAC, Sea Area of the Cook Islands, Vol.1 (2001).

4) JICA/MMAJ: Report on the Cooperative Study Project on the Deepsea Mineral Resources in Selected Offshore Areas of the SOPAC Region, Sea area of the Republic of Fiji Islands, Vol.2 (2002).
5) Kohpina, P. and Usui, A.: 1996, Estimation of Manganese Nodule Resource in the Northern Part of the Central Pacific Basin. Bulletin of the Geological Survey of Japan, 47 (5) (1996), $255-271$

6) JOGMEC: 金属資源レポート (2012-1), pp77-81.

7) N. Okamoto: Occasional Paper, No.41, Kagoshima Univ. Research Center for the Pacific Islands (2005), pp21-30.

8) JOGMEC: 金属資源レポート (2006-1), pp7-16.

9) 白井朗：海底鉱物資源 (オーム社, 2010), pp99-101。 